\title{
Does Top Executive Gender Diversity Affect Earnings Management?
}

\author{
Paskah Ika Nugroho Purnomo
}

Oni Novilia

\begin{abstract}
This research examines the influence of female CEO, female CFO, female board of commissioners, and female audit committee on accrual based earnings management. This research presume that man and woman would act differently to solve a problem. This research using a sample of 304 companies listed on the Indonesian Stock Exchange that selected based on purposive sampling method. Hypothesis testing is performed by using multiple linier regression to examine the effect of each independent variable on the dependent variable. The result of this research showed that the position of CFO who is held by female have a significant negative effect on accrual based earnings management. While the position of female CEO, female board of commissioners, and female audit committee have no significant effect on accrual based earnings management.
\end{abstract}

Keywords: gender, corporate governance, earnings management, accrual based earnings management. 